\title{
BRAZILIAN ROASTED COFFEE OIL OBTAINED BY MECHANICAL EXPELLING: COMPOSITIONAL ANALYSIS BY GC-MS ${ }^{1}$
}

\author{
Alessandra L. de OLIVEIRA²; Paulo Marcio CRUZ³ ${ }^{3}$ Marcos N. EBERLIN ${ }^{4}$; Fernando A. CABRAL ${ }^{5, *}$
}

\section{RESUMO}

ÓLEO DE CAFÉ TORRADO BRASILEIRO OBTIDO POR PRENSAGEM DOS GRÃOS: ANÁLISE DA COMPOSIÇÃO POR GC-MS. Análise preliminar utilizando GC-MS através da comparação dos espectros de massas dos compostos com aqueles da base de dados Wiley 275 L foi feita para identificar ácidos graxos e principalmente componentes voláteis responsáveis pelo aroma e odor do óleo de café torrado. O óleo foi obtido por prensagem dos grãos de café brasileiro (Coffea arabica), torrado a $238^{\circ} \mathrm{C}$ por 10 min. Diferentes metodologias de preparo de amostra como "headspace", adsorção por sucção em armadilha com polímero e esterificação foram usadas. Foi possível identificar pirazinas, piridinas, derivados de furanos e outros componentes ainda não apresentados na literatura.

Palavras-chave: óleo de café, aroma de café, ácidos graxos, extração por prensagem.

\section{SUMMARY}

A preliminary analysis by GC-MS comparing the mass spectrum of the compounds with the Wiley $275 \mathrm{~L}$ mass spectral data base was used to identify the fatty acids and mainly, some volatile compounds responsible for the flavor of the roasted coffee oil. The oil was obtained by mechanical expelling of Brazilian beans (Coffea arabica) roasted at $238^{\circ} \mathrm{C}$ for 10 minutes. Different sample preparation methodologies such as headspace, adsorbent suction trapping and esterification were used. It was possible to identify pyrazines, pyridines, furan derivatives and other compounds not reported in the literature.

Keywords: coffee oil, coffee flavor, fatty acids, GC-MS, pressing extraction.

\section{1 - INTRODUCTION}

The roasted coffee beans are composed of nitrogenous compounds, such as caffeine, trigonelline and pigments, chlorogenic and carboxylic acids, lipids and volatile compounds [2]. Aroma is one of the most important attributes of roasted coffee. The coffee aroma results from a mixture of many classes of volatile compounds, and their concentration and aroma potential vary substantially. The composition of the characteristic coffee flavor depends on several factors such as species/variety of beans, climate, soil conditions (humidity and $\mathrm{pH}$ ), harvest (hand or strip-picked), drying, storage and roasting operational conditions such as time, temperature and equipment [1]. The application of heat, that is, roasting, induces many chemical changes in the green coffee beans, and the aromatic compounds are formed mainly by pyrolisis of the water-soluble compounds present in the beans $[6,7,8]$. The lipid fraction of the beans is little changed during roasting and protects the aroma compounds from degradation as roasting continues [2].

The aromatic fraction is sufficiently soluble in water to impart the characteristic flavor of roasted coffee to a

\footnotetext{
${ }^{1}$ Recebido para publicação em 11/06/2004. Aceito para publicação em 15/09/2005 (001364).

${ }^{2}$ Departamento de Engenharia de Alimentos (ZEA), FZEA, USP - Universidade de São Paulo.

${ }^{3}$ Departamento de Controle de Qualidade, COCAM - Cia. de Café Solúvel e Derivados.

${ }^{4}$ Instituto de Química (IQ), UNICAMP - Universidade Estadual de Campinas.

${ }^{5}$ Departamento de Engenharia de Alimentos (DEA), FEA, UNICAMP - Universidade Estadual de Campinas, C. P. 6121, Barão Geraldo, Campinas, SP, Brasil, CEP: 13083-970 (telefone +55 19 3788-4030, fax +55 19 3788-4025, e-mail: cabral@fea.unicamp.br).

*A quem a correspondência deve ser enviada.
}

beverage $[4,11]$ while the percent lipid fraction in roasted coffee is not a significant factor for the acceptability of the coffee beverage. During beverage preparation, the lipid fraction, not being water-soluble, is mostly retained in the grounds and is discarded. However, the aromatic compounds greatly affect the acceptability of the beverage since they are transferred to the coffee beverage during percolation/filtration [4].

Normally, the extraction of aromatic volatiles from roasted coffee is performed by solvent extraction, the polarity of the solvent being adjusted to extract as many aroma fractions as possible. Another way to obtain the aromatic extract of roasted coffee is by mechanical expelling of the roasted beans. The roasted coffee oil obtained by pressing is composed of a lipid and a volatile fraction typical of the coffee aroma and presents many different properties and applications. When pressing is used, the coffee oil contains a good proportion of the aromatic constituents of medium and low volatility, but these extracts have an intense "burnt" smell due to the partial pyrolisis that occurs during pressing caused by the high pressures and temperatures used. Gaseous, liquid and supercritical carbon dioxide extractions are other techniques, which can be used for aromatic coffee extraction $[16,17,20,21]$.

In Brazil, roasted coffee oil with aromatic properties is obtained by pressing the roasted beans before the extraction of soluble coffee. Figure 1 presents the flow chart of the pressing extraction process of roasted coffee oil used in Brazilian Industries. After pressing, the extracted oil is filtered (press filtered) to remove the larger particles. The oil obtained is rich in pigments, usually with dark brown colors. The roasted coffee oil obtained by mechanical expelling represents an important by-product of the Brazilian 


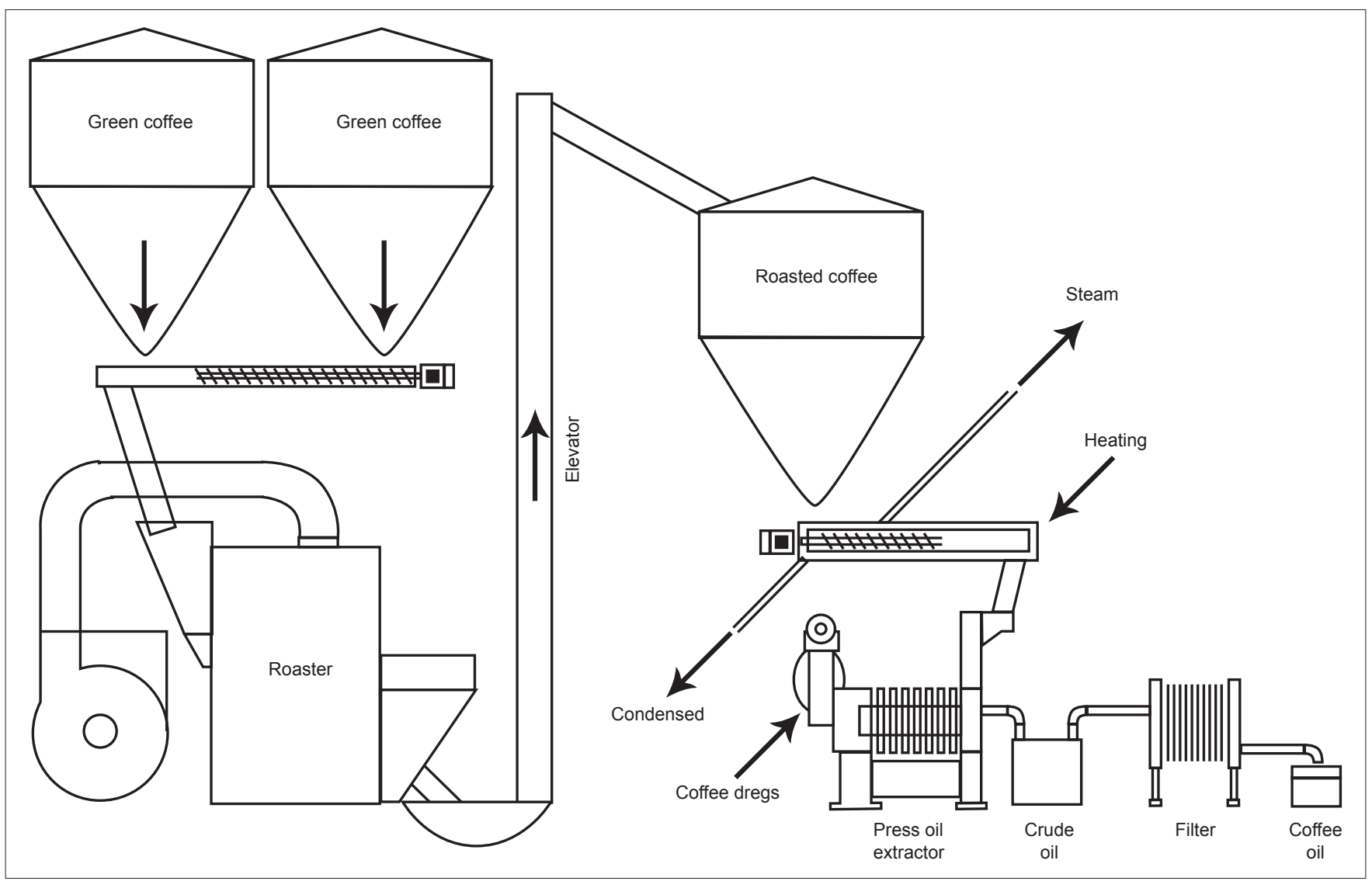

FIGURE 1 - Flow-chart of Brazilian roasted coffee oil extraction by mechanical expelling as applied by the COCAM Company

soluble coffee industries. However, there has been increased concern, lately, over the health effects of certain compounds of the lipid content of the coffee oil, such as the diterpenes cafestol and kahweol [5, 18, 19]. It is important to clarify this question since there is great interest in its use to increase the aromatic potential of the soluble coffee and coffee beverage as a flavoring for candies, cakes and puddings. Normally, the roasted coffee oil is used to minimize the incidence of fine powder when added to soluble coffee. This oil forms a superficial layer and prevents the fragmentation of soluble coffee granules. Due to these possible applications in the food industry and the lack of information in the literature defining the aromatic composition of the Brazilian roasted coffee oil obtained by mechanical expelling, the objective of this research was to identify the compounds responsible for the characteristic coffee flavor of the oil after the mechanical expelling of roasted Brazilian Coffea arabica beans. For this, we have used four different methodologies aiming to test which class of compounds is detected in each one.

\section{2 - MATERIAL AND METHODS}

\section{1 - Brazilian roasted coffee oil samples}

Roasted coffee oil obtained by mechanical expelling of Brazilian Coffea arabica beans, roasted at $238^{\circ} \mathrm{C}$ for 10 minutes, was supplied by the COCAM-Soluble Coffee and Derivatives Company (Catanduva, SP, Brazil). This oil contained mostly triacilglycerols with a reasonable amount of aromatic constituents [2], being typical of the oil produced by Brazilian coffee industries as a source of coffee aroma. Four different sample preparation methodologies and triplicate analysis were performed aiming a preliminary identification of the roasted coffee oil composition by GC-MS:

\section{2 - Direct injection (A)}

The roasted coffee oil was diluted in dichloromethane (EM SCIENCE, Toronto, CA) (1:5) and $1 \mu \mathrm{L}$ of this solution was directly injected into the chromatograph for GC-MS analysis.

\section{3 - Esterification: Fatty acid esters from lipids (B)}

To analyze the fatty acid content of the oil, the sample was treated by $\mathrm{BF}_{3}$-Methanol esterification of the fatty acids [14]. The hexane phase ( $1 \mu \mathrm{L})$, after separation of the remaining solution, was injected into the chromatograph for GC-MS analysis.

\section{4 - Headspace sampling $(C)$}

Roasted coffee oil ( $5 \mathrm{~mL}$ ) was placed in a headspace tube (Varian NMR Instruments, CA, USA) and sealed with a silicon septum. The tube was cooled to $0^{\circ} \mathrm{C}$ and evacuated for 1 minute using a micro syringe (Hamilton Company, 
NV, USA) connected to a vacuum pump. The tube was then placed in a thermostatic bath and heated at $70^{\circ} \mathrm{C}$ for 15 minutes, and the volatile compounds trapped in the headspace region of the tube $(500 \mu \mathrm{L})$ and analyzed by GC-MS using direct gas injection.

\section{5 - Adsorbent suction trapping (D)}

To concentrate the aromatic compounds present in the roasted coffee oil, the sample was submitted to the methodology of volatile capture [3]. Water $(200 \mathrm{ml})$ was added to the roasted coffee oil $(20 \mathrm{~g})$ in a $500 \mathrm{~mL}$ round-bottomed flask and stirred magnetically at low speed. This mixture of roasted coffee oil and water was submitted to a small temperature gradient, from $25^{\circ} \mathrm{C}$ to $70^{\circ} \mathrm{C}$ for 3 hours. The flask was connected to a Porapak-Q (Supelco, PA, USA) trap and the volatiles swept to the trap by suction with a vacuum pump. Pure dichloromethane (EM SCIENCE, Toronto, CA) (2 mL) was applied to one end of the small column and the solvent plus the eluted volatile compounds were collected in a tube cooled at $0^{\circ} \mathrm{C}$. A sample $(2 \mu \mathrm{L})$ of the volatile solution was then analyzed by GC-MS.

\section{6 - Conditions for the GC-MS analysis}

The separation of the roasted coffee oil compounds was carried out using an HP 5890 series III gas chromatograph, equipped with an HP ultra $2(25 \mathrm{~m} \mathrm{x} 0.2$ $\mathrm{mm}$ i.d. $\mathrm{x} 0.33 \mathrm{~mm}$ f.s.p.) capillary column coupled to an HP 5988 quadrupole mass spectrometer. The peaks were identified by comparison with the Wiley $275 \mathrm{~L}$ mass spectra library. Ions were generated by EI at $70 \mathrm{eV}$. The temperature programmer for the chromatograph and mass spectrometer (Table 1 ) was tested and defined according to the four methodologies $(A, B, C$ and $D)$ used to prepare the sample.

\section{3 - RESULTS AND DISCUSSION}

The aromatic fraction of the roasted coffee oil is complex, involving more than 800 compounds with different functional groups [15]. Recently, a number of additional aromatic compounds have been identified and studied with the main focus on identifying which aromatic compounds could be considered individually as important and powerful constituents of coffee aroma [9, 13, 22, 23]. In the present work, it was possible to identify compounds with functional class characteristics of the coffee aroma in the Brazilian roasted coffee oil.

\section{1 - Direct injection $(A)$}

Figure 2 shows the total ion chromatogram obtained for the direct injection of the coffee oil diluted in dichloromethane. From the respective mass spectra and using their spectra agreement index, it was possible to identify caffeine, some free fatty acids (palmitic, linoleic, and stearic acids) and some volatile compounds, as listed in Table 2. Caffeine is present in considerably large amounts in the green coffee and after roasting, because it is not thermally degraded. Thus, during the mechanical expelling extraction, the caffeine is incorporated into the roasted coffee oil.

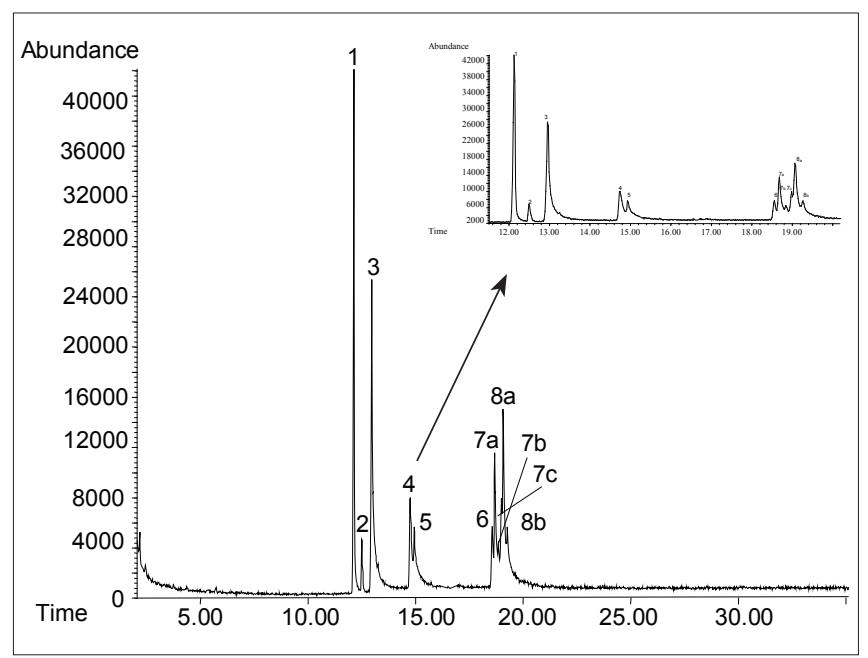

FIGURE 2 - GC-MS total ion chromatogram (TIC) of the roasted coffee oil diluted in dichloromethane

\section{2 - Esterification: fatty acid esters from lipids $(B)$}

The total ion chromatogram (Figure 3) shows improved resolution of the methyl esters. The total ion chromatogram is clear and only shows the fatty acids since after esterification, probably the other compounds present are degraded and the fatty acids esters from lipids have better resolution. It was possible to identify five different fatty acids present in the

TABLE 1 - Conditions used for the GC-MS analysis of the roasted coffee aromatic oil samples

\begin{tabular}{|c|c|c|c|c|c|c|}
\hline Method & $\begin{array}{c}\text { Oven initial } \\
\text { temperature }\left({ }^{\circ} \mathrm{C}\right)\end{array}$ & $\begin{array}{c}\text { Oven final } \\
\text { temperature }\left({ }^{\circ} \mathrm{C}\right)\end{array}$ & $\begin{array}{c}\text { Injector } \\
\text { temperature } \\
\left({ }^{\circ} \mathrm{C}\right)\end{array}$ & $\begin{array}{c}\text { Detector } \\
\text { temperature }\left({ }^{\circ} \mathrm{C}\right)\end{array}$ & $\mathrm{m} / \mathrm{z}^{*}$ range & Splitless ${ }^{\#}$ injection \\
\hline$A$ & 150 with gradual increases of $4 / \mathrm{min}$. & 300 for $5 \mathrm{~min}$. & 270 & 285 & $40-500$ & - \\
\hline$B$ & 150 for 3 min. with gradual increases of $2 / \mathrm{min}$. & 250 for $5 \mathrm{~min}$. & 250 & 280 & $50-500$ & - \\
\hline C & 60 with gradual increases of $4 / \mathrm{min}$. & 250 for $10 \mathrm{~min}$. & 120 & 270 & $40-500$ & 0.75 \\
\hline$D$ & 60 for $10 \mathrm{~min}$. with gradual increases of $2 / \mathrm{min}$. & 150 for $5 \mathrm{~min}$. & 150 & 270 & $50-500$ & - \\
\hline
\end{tabular}

A: Direct injection; B: Esterification: fatty acid esters from lipids; C: Headspace sampling; D: Adsorbent suction trapping

*Mass spectrum acquisition was performed in the mass range from 40 to $500 \mathrm{~m} / \mathrm{z}$

"Injection used for trace analysis (most of vaporized sample goes onto the column) 
TABLE 2 - Some compounds identified by GC-MS in the roasted coffee oil diluted in dichloromethane

\begin{tabular}{|c|c|c|c|c|}
\hline Peak & Retention time & Compound & Reference & Spectra agreement index \\
\hline 1 & 12.14 & caffeine & - & 97 \\
\hline 2 & 12.51 & diphenylsulfone & - & 91 \\
\hline 4 & 14.75 & cis-9, cis-12-octadecadienoic acid (Linoleic acid) & [10] & 98 \\
\hline 5 & 14.95 & octadecanoic acid (Stearic acid) & [10] & 94 \\
\hline 6 & 18.56 & 2-vinyl-2,3-dihydrobenzofuran & - & 47 \\
\hline $7_{\mathrm{b}}$ & 18.84 & 3-buten-2-none, 4-phenyl & - & 50 \\
\hline $7_{\mathrm{c}}$ & 18.98 & 2-phenyl-3-(4-methoxyphenyl)indene & - & 78 \\
\hline 8 a & 19.06 & 2-[1-(2,4-dimethoxyphenyl)vinyl]phenol & - & 83 \\
\hline 8 b & 19.08 & 12-methoxy-3-methylcholanthrene & - & 86 \\
\hline
\end{tabular}

[10] Compounds with reference have been previously reported in the literature

lipid fraction of the oil: palmitic, linoleic, oleic, stearic and arachidic acids (Table 3 ). The composition of the fatty acids of coffee oil was previously studied, showing similar results to those found in the Brazilian roasted coffee oil [10].

\section{3 - Headspace sampling (C)}

Headspace was shown to be an inappropriate sampling method for the identification of the aromatic fraction of roasted coffee oil. For this methodology, the volatile concentration

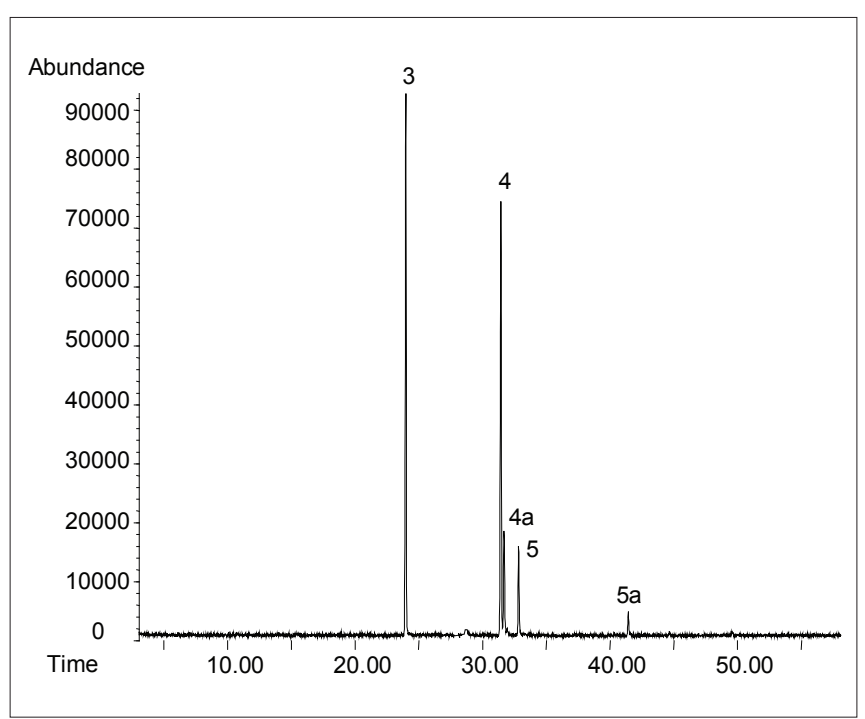

FIGURE 3 - GC-MS total ion chromatogram (TIC) of the roasted coffee oil after BF3-Methanol trans-esterification that goes to the gas phase is not sufficient to be detected in GC/MS analysis. However, nine volatile compounds could be identified but with low intensity. Table 4 lists the selfintegration and the compound associated with each total ion chromatographic peak. The spectra agreement index corresponding to the identified compound displays low values owing to the signal-to-noise ratio. Note, however, that some of the compounds identified have been reported in the literature as constituents of coffee aroma.

\section{4 - Adsorbent suction trapping $(D)$}

To detect larger amounts of the less volatile compounds present in the roasted coffee oil, volatile suction trapping in a Porapak-Q adsorbent was applied. A well resolved and much more intense total ion chromatogram was obtained (Figure 4) and a larger amount of compounds with relatively lower volatility was detected.

Table 5 presents the retention times and the spectra agreement index of each identified compound via its mass spectra analysis. Pyrazines [2, 7], one furan [1], two ketones [22, 23], one phenol [9] and two alcohols [20, 21] were present, but the great majority were aromatic hydrocarbons $[3,4,5,6,8,15,16,17,18,19]$ and other hydrocarbons $[10,1112,13,14]$.

Analyzing the four methodologies, it is suggested that the lipid fraction should be analyzed using the same methodology applied for evaluation of vegetal oils, applying the principle of fatty acids esterification. Direct injection could contribute for the analysis of the some volatiles, free fatty

TABLE 3 - Total fatty acids present in roasted coffee oil identified by GC-MS

\begin{tabular}{|c|c|c|c|c|c|}
\hline Peak & Retention time & Compounds ${ }^{[10]}$ & Fatty acids & MW & $\begin{array}{c}\text { Spectra agreement } \\
\text { index }\end{array}$ \\
\hline 3 & 23.99 & hexadecanoic acid, methyl ester & Palmitic & 256.42 & 98 \\
\hline 4 & 31.45 & cis-9, cis-12-octadecadienoic acid, methyl ester & Linoleic & 208.44 & 99 \\
\hline $4 a$ & 31.70 & cis-10-octadecadecenoic acid, methyl ester & Oleic & 282.45 & 99 \\
\hline 5 & 32.84 & octadecanoic acid, methyl ester & Stearic & 284.47 & 99 \\
\hline 5 & 41.44 & eicosanoic acid, methyl ester & Arachidic & 312.52 & 94 \\
\hline
\end{tabular}

[10] Compounds with reference have been previously reported in the literature MW: molecular weight 
Compositional analysis of roasted coffee oil, Oliveira et al.

TABLE 4 - Some volatile compounds identified by GC-MS from the headspace of the roasted coffee oil

\begin{tabular}{lclcc}
\hline Peak & Retention time & Compound & Reference & Spectra agreement index \\
\hline 1 & 3.19 & pyridine & {$[12]$} & - \\
20 & 49 \\
2 & 4.65 & 4-methyl pyridine & [17] [12] [25] & 49 \\
3 & 4.73 & pyrazine, methyl & {$[17]$} & 58 \\
$4 / 5$ & $5.58 / 5.72$ & 2-furanmethanol & - & 49 \\
6 & 7.70 & 1,2-benzenediamide & {$[25]$} & 58 \\
7 & 7.76 & 2-(2-propenyl)-furan & - & 47 \\
8 & 7.85 & 1,2-benzenediamide & {$[17][25]$} & 58 \\
9
\end{tabular}

[17], [12], [25]: Compounds with reference have been previously reported in the literature.

TABLE 5 - Some volatile compounds identified in the roasted coffee oil after suction trapping (Porapak-Q)

\begin{tabular}{|c|c|c|c|c|}
\hline Peak & Retention time & Compound & Reference & Match \\
\hline 1 & 14.13 & furfuryl acetate & [17] [12] & 94 \\
\hline 2 & 14.54 & pyrazine, 2-ethyl-3-methyl & [12] & 88 \\
\hline $4^{\#}$ & 18.49 & 1,4-diethylbenzene & - & 94 \\
\hline $5 / 6^{\#}$ & $18.85 / 19.14$ & 1,2-diethylbenzene & - & 97 \\
\hline 9 & 21.32 & phenol, 2-methoxy (Guaiacol) & [17] [22] [23] [25] & 82 \\
\hline 10 & 24.10 & 1-methyl-1-(1-methylethenyl)cyclopentane & - & 70 \\
\hline 11 & 24.69 & cis,cis,trans-1-isobutyl-2,5-dimethylcyclohexane & - & 94 \\
\hline 12 & 25.09 & 3-ethyl-5-methyl-1-propyl-cyclohexane & - & 90 \\
\hline 13 & 25.47 & 4-undecene, 4-methyl & - & 82 \\
\hline 17 & 29.73 & benzene, 1,3,5-trimethyl-2-propyl & - & 84 \\
\hline 18/19\# & $31.63 / 32.85$ & benzene, 1,3,5-trimethyl & - & 93 \\
\hline 20 & 33.19 & isothymol & - & 83 \\
\hline 21 & 33.96 & benzenemethanol, 4-(1-methylethyl) & - & 83 \\
\hline $22 / 23$ & $34.49 / 35.82$ & ethanone, 1-(4-ethylphenyl) & - & 94 \\
\hline
\end{tabular}

[4], [12], [17], [22], [23], [25]: Compounds with reference have been previously reported in the literature; ${ }^{*}$ compounds contaminating the Porapak- $Q$ polymer are present in the samples when previous treatment is not made. For its identification, it is necessary to use a blank.

acids and caffeine in the sample. The headspace can be considered impracticable when carried out in the conditions used in this work; however the methodology that uses adsorbent trapping showed to be widely satisfactory since it is simple and easily applied for aromatic composition analysis of the roasted coffee oil.

\section{4. - CONCLUSIONS}

The Brazilian roasted coffee oil is obtained by mechanical expelling of Coffea arabica before the extraction of the soluble coffee, and because of this, shows high quality and is widely used in food industries as characteristic flavor of roasted coffee. The total fatty acid composition of the lipid fraction and some characteristic volatile compounds present in the roasted coffee aroma were identified by GC-MS. Some of

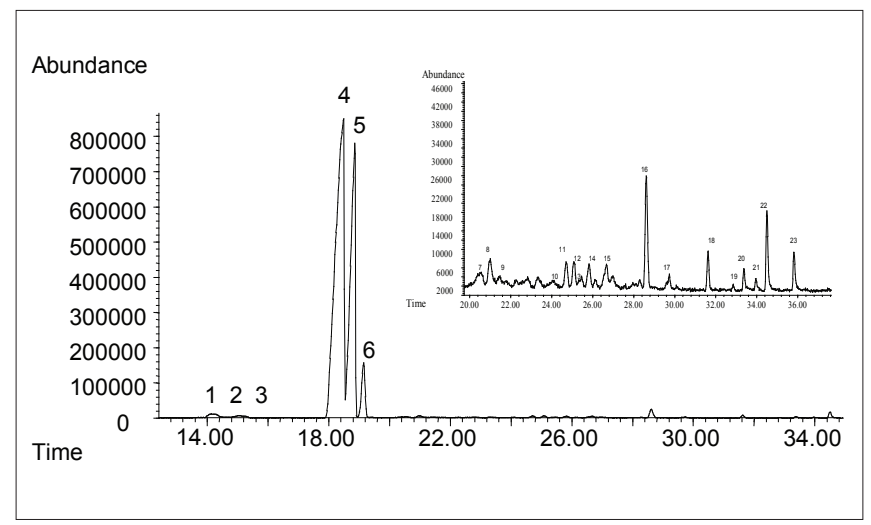

FIGURE 4. GC-MS total ion chromatogram (TIC) of the volatiles trapped from the roasted coffee oil by Porapak- $Q$ 
these compounds had already been reported in the literature and some were preliminarily identified here as presented in Tables 4 and 5 . The free and total fatty acid compositions of the coffee beans are already known and display very little variation according to coffee type and origin. The four sample preparation methodologies tested in this study showed that headspace sampling was inadequate for the analysis of volatiles, because the lipid fraction is such a good solvent and prevented their transfer to the headspace. Many aromatic and other hydrocarbons, pyrazines (pyrazine, methyl; pyrazine, 2-ethyl-3-methyl; pyrazine, 3-ethyl, 2,6-dimethyl), furans (2-vinyl-2,3-dihydrobenzofuran; 2,3-dimethylbenzofuran; 2furanmethanol; furfuryl acetate) and ketones (3-buten-2-none, 4-phenyl; ethanone, 1-(4-ethylphenyl)), which are characteristic compounds of coffee aroma, were identified by applying GC-MS analysis. Other characteristic compounds of the roasted coffee aroma with high volatility were not identified. Maybe the high temperature used in the mechanical expelling results in some volatile compounds being lost during the process. It was not possible to identify the diterpenes cafestol and kahweol in the Brazilian coffee oil using these four analytical methodologies. However, forthcoming studies should be conducted to identify these compounds, to clarify this question since there is great interest in food industry applications.

\section{5 - LIBRARY REFERENCE}

[1] BAREL, M.; JACQUET, M. La qualité du café ses causes son appréciation, son amélioration, Plantation, Recherche, Developpement, Juillet-Aôut, p. 5-13, 1994.

[2] FOLSTAR, P. Lipids. In: CLARKE, R.J.; MACRAE, R. (Ed) Coffee-Chemistry. London/New York: Elsevier Applied Science Publishers, 1985. v. 1, p. 203-220.

[3] FRANCO, R.B.; RODRIGUEZ-AMAYA, D.B. Trapping of sousop (Annona muricata) juice volatiles on Porapak-Q by suction, J. Sci. Food. Agric, v. 34, p. 293-299, 1983.

[4] FRIELD, P.; KRAMPL, V.; RADFORD T.; RENNER, J.A; SHEPHARD, F.W.; GIANTURCO, M.A. Some constituents of the aroma complex of coffee, J. Agric. Food Chem., v. 19, p. 530-532, 1971.

[5] GROSS, G.; JACCAUD, E.; HUGGETT, A.C. Analysis of the content of the diterpenes cafestol and kahweol in coffee brews, Food Chem. Toxicol., v. 35, p. 547554, 1997.

[6] GWEN, L.; BEMIS-YOUNG, G.L.; HUANG, J.; BERNHARD, R.A. Effect of $\mathrm{pH}$ on pyrazines formation in glucose-glycine model systems, Food Chem., v. 46, p. 383-387, 1993.

[7] HASHIM, L.; CHAVERON, H. Use of methylpyrazine ratios to monitor the coffee roasting, Food Res. Int., v. 28, p. 619-623, 1996.

[8] HOFMANN, T.; SCHIEBERLE, P. Identification of potent aroma compounds in thermally treated mixtures of glucose/cysteine and rhamnose/cysteine using aroma extract dilution techniques, J. Agric. Food Chem., v. 45, p. 898-906, 1997.

[9] HOLSCHER, W.; VITZTHUM, O.G.; STEINHART, H. Phenyl alcohol-Source for odorants in roasted coffee, J. Agric. Food Chem., v. 40, p. 655-658, 1992.

[10] KHAN, N.A.; BROW, J.B. The composition of coffee oil and its component fatty acids, J. Am. Oil Chem. Soc., December, p. 606-609, 1953.

[11] LEE, S. Oil and the Coffee beverage, Tea and Coffee Trade Journal, July, p. 14-25, 1971.

[12] LIARDON, R.; OTT, U. Application of multivariate statistics for the classification of coffee headspace profiles, Lebensm.-Wiss. u.-Thechnol., v. 17, p. 32-38, 1984.

[13] MAYER, F.; CZERNY, M.; GROSCH, W. Sensory study of the character impact aroma compounds of coffee beverage. Eur. Food Res. Technol., v. 211, p. 272-276, 2000.

[14] METCALFE, L.D.; SHMITZ, A.A.; PELKA, J.R. Rapid preparation of fatty acid esters from lipids for gas chromatographic analysis, Anal. Chem., v.38, p. 514515, 1966.

[15] NIJSSEN, L.R.; VISSCHER, C.A.; MAARSE, H.; WILLEMSENS L.C.; BOELENS, M.H. Volatile Compounds in Food, The Netherlands: TNO-CIVO, Food Analysis Institute, 1996.

[16] OLIVEIRA, A.L.; SILVA, S.S.; DA SILVA, M.A.P.; EBERLIN, M.N.; CABRAL, F.A. Sensory and yield response surface analysis of supercritical $\mathrm{CO}_{2}$ extracted aromatic oil from roasted coffee. J. Food Sci. Tech., v. 38, p. 38-42, 2001.

[17] RAMOS, E.; VALERO, E.; IBÁNÈS, E.; REGLERO, G.; TABERA, J. Obtention of brewed coffee aroma extract by optimized supercritical $\mathrm{CO}_{2}$-based process, J. Agric. Food Chem., v. 46, p. 4011-4016, 1998.

[18] RATNAYAKE, W.M.N.; HOLLYWOOD, R.; O'GRADY, E.; STAVRIC, B. Lipid content and composition of coffee brews prepared by different methods, Food Chem. Toxicol., v. 31, p. 263-269, 1993.

[19] RATNAYAKE, W.M.N.; PELLETIER, G.; HOLLYWOOD, R.; MALCOLM, S.; STAVRIC, B. Investigation of the effect of coffee lipids on serum cholesterol in hamsters, Food Chem. Toxicol., v. 33, p. 195-201, 1995.

[20] ROSELIUS, W.; VITZTHUM, O.; HUBERT, P. Method of extracting coffee oil containing aroma constituents from roasted coffee, U.S. Patent 4,328,255, 1982.

[21] SARRAZIN, C., QUÉRÉ, J.L.; GRESTSCH, C.; LIARDON, R. Representativeness of coffee aroma extracts: a comparison of different extraction methods, Food Chem., v. 70, p. 99-106, 2000.

[22] SEMMELROCH, P.; GROSCH, W. Analysis of roasted coffee powders and brews by gas chromatographyolfactometry of headspace samples, Lebensm.-Wiss. u.-Thechnol., v. 28, p. 310-313, 1995.

[23] SEMMELROCH, P.; GROSCH, W. Studies on character impact odorants of coffee brews, J. Agric. Food Chem., v. 44, p. 537-543, 1996.

[24] SILMAR, R.; LÜLLMANN, C. Investigation of aroma formation in robusta coffee during roasting, Café Cacao Thé, v. XXXVII, p. 142-145, 1993.

[25] WHANG, T.H.; SHANFIELD, H.; ZLATKIS, A. Analysis of trace volatile organic compounds in coffee by headspace concentration and gas chromatographymass spectrometry, Chromatographia, v, 17, p. 411-417, 1983.

\section{6 - ACKNOWLEDGEMENT}

This research was funded by the State of São Paulo Research Foundation (FAPESP) Brazil (Grant 96/1 1904-0). 